\title{
Chinese Ethnic Communication Pattern in the Environment of Indigenous People in Lhokseumawe, Indonesia
}

\author{
Muhammad Saleh ${ }^{1,3}$, Syukur Kholil ${ }^{2}$, Ahmad Tamrin Sikumbang ${ }^{2}$ \\ ${ }^{I}$ Ph.D Student in Islamic University of North Sumatera (UINSU), Medan, Indonesia \\ ${ }^{2}$ Islamic University of North Sumatera (UINSU), Medan, Indonesia \\ ${ }^{3}$ Islamic Religion Institute (IAIN), Lhokseumawe, Indonesia \\ tgkdrsaiful@gmail.com
}

\begin{abstract}
This paper entitled Chinese Ethnic Communication Pattern in the Environment of Indigenous People in Lhokseumawe, Indonesia. To be used as the basis for the formulation of the research problems written in this paper, namely: how is the communication pattern of LhokseumaweChinese ethnic in the indigenous people in Lhokseumawe. So that the writer can find the communication pattern of LhokseumaweChinese ethnic in the indindigenous people in Lhokseumawe, as the writing patron the writer uses the method in this study is a qualitative research method with the aim to explain the phenomenon deeply, through a phenomenological approach. The process of data collection techniques through observation, unstructured interviews, and documentation while data analysis techniques are carried out in three ways, data reduction, displaying data, and drawing conclusions. To strengthen this research is supported by three theories, namely the theory of Symbolic Interaction, Turgic Drama theory, and Goffman'sSelf Presentation. The results of this study indicate that, the communication pattern of LhokseumaweChinese ethnic in the indigenous people in Lhokseumawe is done by cultural adaptation. Chinese ethnic communities try to find sympathy for indigenous people by promoting symbolic interaction and identity manipulation.
\end{abstract}

Keywords: chinese ethnic; communication pattern; indigenous people; lhokseumawe

\section{Introduction}

Indonesia is one of the largest countries in the world whose population consists of various ethnicities, races, and cultures spread throughout the archipelago. This diversity makes the Indonesian people believe in culture, and at the same time tend to be open to immigrants and change. The Indonesian people scattered throughout Indonesia consist of indigenous people who have inhabited thousands of years until the arrival of migrant communities called as foreign communities, namely Arab descendants and Chinese descendants. This difference has been eastern conveyed by Allah SWT in the Qur'an which sounds.

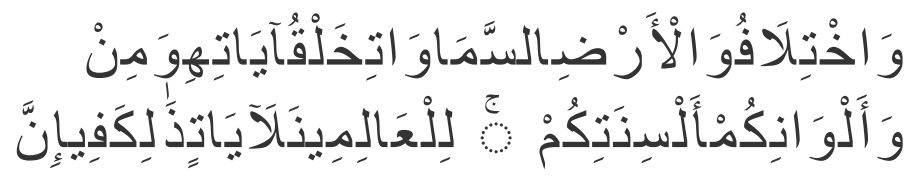

Meaning:

And among His signs of power is to create the heavens and the earth and your various languages and the color of your skin. Verily in that there are indeed signs for those who know. (Ar-Rum: 22)

Long before Indonesia's independence, Dutch colonial policy had planted seeds of conflict between the Chinese and the indigenous population. The Dutch colonial government distinguished Chinese ethnic positions with indigenous peoples to support the fulfillment of their goals in Indonesia, namely imperialism. Most Chinese people control the trade very 
much, especially in the countryside. In addition, politically and socially, ethnic Chinese are very much tied to the behavior and attitudes of their ancestral culture, so that they seem exclusive and do not want to be involved in practical political circles. Until now, Chinese ethics generally prefer trade to others.

As a result of this discrimination, the Chinese consider themselves to be of higher status than Indonesians. The country of Indonesia as a multi-ethnic nation, faced with the problem that the Indonesian people of Chinese descent as ethnic groups, had the same rights as other ethnic groups such as China, Sunda, Maluku, Java, Aceh and others ${ }^{1}$. So far in Indonesia, Chinese descendants have limited their movement in the trade sector but have not been given the same rights in the fields of education and politics. even mandarin in the New Order should not be taught in public schools, even though in reality at this time the concept of the new order government had vanished.

Chinese people are also very attached to the ideology and culture of their past and obedient to the teachings of the congress, one of the teachings of the congregation is a strong belief about the relationship between the past and present, the Chinese are very high in the past and ancestors and ancestors. the past. The past is a mirror of the success of the present, they make the past a memory that must be used as a first step towards a more brilliant future.

The results of the Ku Cheng Sun study in Taiwan confirm that in Chinese business family relationships and interpersonal relations networks are still held and are a very important element in operating large-scale companies. Interpersonal relationships and personal trust are very prominent in business relationships. That is, if someone wants to be transferred or employed to a Chinese-owned company, it must get a recommendation and be trusted throughout the life of family relations to become one of the characteristics of Chinese ethnic business including in Indonesia. ${ }^{2}$

Chinese ethnic communities are widespread in the archipelago, including Aceh. In Aceh, especially the City of Lhokseumawe, most of them consist of the Khek (Hakka) tribe. Hakka people are one of the Chinese groups, the language used is the Hakka language which is commonly called Khek, a language spoken by Hakka people. This is the Han tribe which is spread in the mountains of Guangdong, Fujian and Guangxi Provinces. Ethnic Chinese were present in Aceh on a large scale in $1875 .^{3}$ They were brought in by the Dutch to be employed as laborers. Their presence in Aceh at that time opened the cultural contact between Aceh and Chinese culture, which before Acehnese had cultural contact with Indians, Arabs and Europeans. On the one hand, ethnic Chinese merchants are reluctant to blend even when sitting together with indigenous people and they attach great importance to their own nation so that they feel like they are more closed to indigenous people.

Similarly, the relationship between ethnic Chinese and ethnic Aceh is not always harmonious. This fact is because the two ethnic groups have different cultural backgrounds. Cultural contact continues to this day so that acculturation occurs, for example in welcoming the New Year, Chinese people in Aceh are celebrated to be fortified by hitting Beduk. On the other hand, ethnic Chinese Aceh are very few who can speak Aceh, except Chinese who live in the cities of the District. ${ }^{4}$

\footnotetext{
${ }^{1}$ Liem, Yusiu, Prasangka Terhadap Etnis Cina, (Jakarta: Djambatan, 2000), p. 1

${ }^{2}$ Usman, A. Rani , Etnis Cina Perantauan di Aceh..., p. 3

${ }^{3}$ Sulaiman, dkk, Perdagangan, Pengusaha Cina, Perilaku Pasar, (Jakarta: Pustaka Grafika Kita, 1988), p. 22

${ }^{4}$ Usman, A. Rani , Etnis Cina Perantauan di Aceh..., p. 4
} 
Besides that the majority of Acehnese are Muslim, but very few ethnic Chinese embrace Islam, but they are very close to Islamic words such as saying Alhamdulillah, also having a name that is synonymous with Islamic cultural contact which is very often the case through business, and reality this is very vulnerable to conflict. It was this social and cultural distance that finally sparked the 1981 civil conflict which began with the beating of Zakaria, a citizen of Banda Aceh who repaired his motorcycle at the Asihin Chinese shop. These events led to the outbreak of student demonstrations throughout Aceh. The beating of Zakaria was the beginning of the eruption of anti-Chinese demonstrations in Aceh.

\section{Review of Literature}

\subsection{Intercultural Communication}

Intercultural communication is actually an academic study categorized as a science group born later, if we trace its existence starting in the $1950 \mathrm{~s} .{ }^{5}$ The term Interculture (Interculture), was first introduced by an anthropologist, Edward T. Hall in 1959 in his book The Silent Language. Intercultural Communication is one of the fields of study in communication science. Intercultural Communication as a formal object that has been used as a study of science certainly has a theory. The formation of theories in intercultural communication certainly has the power to discuss humanitarian issues between cultures. In short, the theories of intercultural communication are theories that specifically generalize the concept of communication among communicators with different cultures, and who discuss the influence of culture on communication activities. ${ }^{6}$

Society is basically a human who has always inherited and inherited culture from generation to generation. Community culture and behavior are formed because they influence each other in people's lives. This is because subtassively humans are creatures who have the need for interdependent social interactions and cannot live alone. Culture is very influential in shaping people's behavior. Community life behavior is formed by several factors including environmental factors both the environment and the environment in the form of globalization. The influence of globalization also greatly affects the lives of people. This can be seen through acculturation of western culture in local culture.

Cultural interaction in the study of intercultural communication (Intercultural Communication), is the interaction between individuals with different cultural backgrounds. These individuals do not necessarily have to come from different countries, or these individuals do not have to be from a different region. However, also from the same region. For example, Aceh is an area consisting of 13 tribes and 13 local languages, such as tribes and languages of Aceh, Gayo tribes and languages, tribes and languages of Tamiang, Singkil tribes and languages, and so forth. Therefore, even though they are in the territory of the Aceh Province, they have different tribes and languages. Even ethnic Chinese are also classified as ethnic who have long inhabited Aceh, of course interacting with many indigenous people and even many from ethnic Chinese communities in Lhokseumawe who claim that their ancestors lived in Aceh before the existence of the Republic of Indonesia. This certainly requires a study of intercultural communication as the development of communication science and even Islam itself has taught us that we can communicate well, as Allah says in surat Al-baqarah which means:

\footnotetext{
${ }^{5}$ Liliweweri, Alo, Gatra-Gatra Komunikasi.....p. 1

${ }^{6}$ Liliweri, Alo, Gatra-Gatra Komunikasi Antar Budaya, Cet.1, (Yogyakarta: Pustaka Pelajar, 2001), p.29.
} 
And (remember), when We took the promise from the Children of Israel (ie): do not worship other than Allah, and do good to the father, relatives, orphans, and the poor, and speak good words to humans, establish prayer and give alms. then you do not fulfill the promise, except a small portion of you, and you always turn away. (QS. AlBaqarah: 83).

\subsection{Theory of Symbolic Interaction}

The focus of the theory in this study is the Symbolic Interaction Theory. Understanding of symbolic interaction is a way of thinking about mind (mind), self and society that has contributed to the sociocultural tradition in building communication theory. By using sociology as a foundation, this notion teaches that when humans interact with each other, they share meaning for a certain period of time and for certain actions. This theory was stated by Geogrge Hebert Mead. He taught that meaning appears as a result of interactions between humans both verbally and nonverbally. ${ }^{7}$ This symbolic interaction theory inherited the tradition and intellectual position that developed in Europe in the 19th century and crossed into America, especially in Chicago, this city became the center of development of theories and schools of descent from the Frankfurt school. According to JaromeManis and Bernard Meltezer in Littlejhon there are seven basic propositions of symbolic interaction which essentially that:

1. Humans understand something, through meanings obtained from experience. Human perception always appears using symbols.

2. The meaning is learned through intraction between humans, and meaning arises from the exchange of symbols in social groups.

3. All social structures and institutions are based on interactions between humans.

4. Human behavior is not only influenced by events, but by his own will.

5. The human mind contains conversations of an internal nature, which reflect that he has interacted with others.

6. Behavior is created in interactions with social groups.

7. A person cannot be understood only from behavior that is open but must be as a whole. $^{8}$

Scientists who embrace symbolic interactionism say that researching social science is most appropriate to use the theory of symbolic interaction, because a condition goes according to the subejek view itself rather than based on the experience of an outsider or the researcher. Subjeklah that determines everything. Therefore symbolic interactionists suggest that researching social science especially those related to culture is very suitable to use symbolic interaction. Herbert Blumer's symbolic interactionist assumption is as follows:

1. Humans act on something based on the meanings that these objects have for them.

2. The meaning is the result of social interaction in human society.

3. Meanings are modified and handled through an interpretive process used by each individual in his involvement with the signs he faces. ${ }^{9}$

\footnotetext{
${ }^{7}$ Morissan, Teori Komunikasi Indivisu Hingga Massa, (Jakarta: Kencana, 2014), p. 111

${ }^{8}$ Deddy Mulyana, Perkembangan Teori Komunikasi, (Bahan Ajar, 2001) p. 3

${ }^{9}$ Craib, IAI, Teori-Teori Sosial Modern, (Jakarta : Raja GrafindoPersada,1994) p. 112.
} 
Other experts, George Ritzer summarizes the theory of symbolic interaction into the following principles:

1. Humans, unlike lower animals, are endowed with the ability to think.

2. The ability to think is formed by social interaction.

3. In social interaction people learn meaning and symbols that allow them to apply theirdistinctive abilities as humans, namely thinking.

4. Meanings and symbols allow people to continue action (action), and interactions that aretypical of humans.

5. People can modify or change the meanings and symbols they use in actions andinteractions based on their interpretation of the situation.

6. People are able to make modifications and changes because, among others, their ability tointeract with themselves, which allows them to examine the stages of action, assess the relative advantages and disadvantages, and then choose one of them.

7. These intertwined patterns of actions and interactions form groups and communities.

As is known that humans are as thinking creatures as well as the ability to think is formed by the existence of social interaction in society. Humans in interacting with other individuals can use these thinking skills to interpret the meanings around them. With the meaning, humans can continue their actions in their communities and environments. Humans change symbols and their meanings around transmigration based on the interpretation of transmigration itself. Besides that Mead mentions the following:

a. Nature objects are taken from the meaning they have that meaning is created from peoplewho consider it as an object.

b. The meaning arises from how someone is ready to act against him.

c. Someone will act based on that object.

d. Because the object is something that is designated, then someone can act according to his willingness to object. ${ }^{10}$

\subsection{History of Chinese Ethnic Societies}

The history of Chinese society in Indonesia began at the arrival of the ChineseIndonesian Ancestors immigrated in waves since thousands of years ago. The arrival of Chinese people from Tingkok to Indonesia was not synchronous or in waves. It happened according to their trade cycle carried out in Southeast Asia, including Indonesia. Ancient records from China state that the ancient kingdoms in the Archipelago were closely related to the ruling dynasties in China.

It is estimated that since the third century, this factor has subsequently nourished trade and traffic in trade goods from China to the archipelago, and vice versa. The term "China" in the Indonesian press in the 1950s has been changed to "Chinese" (according to his words in Hokkien) to refer to the Chinese and "Chinese" for the Chinese state in the 1950s Indonesian press. According to Purcell, Chinese ethnicity is all Chinese state immigrants and their descendants who live within the scope of Indonesian culture and do not depend on their nationality and the language they use. ${ }^{11}$ Chinese ethnics are individuals who see themselves as "Chinese" or are considered by their environment. At the same time they are related to other overseas Chinese or Chinese countries socially, regardless of nationality, language, or

\footnotetext{
${ }^{10}$ H.R. Riyadi, Interaksionis Simbolik..., p.164.

${ }^{11}$ Leo Suryadinata. Negara dan Etnis Tionggghoa, (Jakarta: LP3ES, 2002), p. 23
} 
close links with Chinese culture. According to Liem, ethnic Chinese in Indonesia are Indonesians from China and since the first / second generation have lived in the country of Indonesia, and mingled with the local population, and mastered one or more languages used in Indonesia. ${ }^{12}$

Indonesian Chinese are the largest minority group in Indonesia. In 1961, they were estimated at around 2.45 million people or approximately 2.5 percent of the total Indonesian population at that time43. Stereotypes circulating in Indonesia often portray Indonesian Chinese as an established and established group, especially when compared to other Indonesians. If most Indonesians live as agrarian communities in the countryside, the Indonesian Chinese instead live concentrated as intermediate traders. Chinese people began arriving in Indonesia in the IX century, namely during the Tang Dynasty 618-907 this dynasty was a dynasty which had strong military power consisting of nomadic forces trained to be reliable cavalry, this dynasty also allied also with the Uighiur tribe who had left the Turkish confederation and became staunch supporters of the Tang dynasty began to trade and seek new life. ${ }^{13}$

These migrants have expertise in their respective fields such as trading goods that are generally in the form of ceramics, household appliances and silk fabrics, and also become craftsmen or become plantation workers. ${ }^{14}$ Massive migration of the Chinese to the Archipelago (now called Indonesia), which reached its peak in the nineteenth century and the beginning of the twentieth century, was part of the migration of Chinese to the whole world. Ancestors of Chinese-Indonesian immigrated in waves since thousands of years ago.

Records from China state that the ancient kingdoms in the Archipelago were closely related to the ruling dynasties in China. This factor then fosters trade and goods and human traffic from China to the archipelago and vice versa. The beginning of the arrival of ethnic Chinese in Indonesia began in the heyday of the Kingdom of Kutai in the interior of Kalimantan, or the Kutai District, which was the area rich in gold mining that they needed as clever jewelers (Gold). Because the need for goldsmiths is increasing, gold is imported from mainland China, in addition to participating in the group are building and trading workers. ${ }^{15}$

They settled to spread starting from Kutai Regency, Sanggau Pontianak and the surrounding area. The second wave of ethnic Chinese (Chinese) arrivals to Indonesia was during the Singosari kingdom in the Malacca region of East Java now.

Their arrival under the marine army was Khubilaikan (Jhengiskan) in the context of expanding its territory. But this first envoy did not immediately settle down, this was due to the King's rejection of the envoy. On the second expedition of the sea army Khubilaikan to the land of Java with the aim of replying to King Singasari's treatment of their previous envoys, but they did not see the kingdom again, and finally landed on a beach called Loa sam (now Lasem) as their fleet along the coast and landed somewhere that Sam Toa Lang Yang later became Semarang.

The ethnic Chinese community then established a place of worship (Kelenteng) which can still be seen today. ${ }^{16}$ Because of the collapse of Singosari and Majapahit, as well as the emergence of a new kingdom namely Demak as an Islamic empire, the existence of this

\footnotetext{
${ }^{12}$ Liem, Yusiu. Prasangka Terhadap Etnis Cina, (Jakarta: Djambatan, 2000) p. x

${ }^{13}$ Jansen Sinamo dan Eben Ezer Siadari. The Chinese Ethos. (Jakarta: Darma Mahardika. 2013) p. 99

${ }^{14}$ Ibid, p. 95

${ }^{15}$ Pramoedya A. Toer. Hoakiau di Indonesia.( Jakarta: Graha Budaya,1998),p. 175.

${ }^{16}$ Pramoedya A. Toer. Hoakiau di Indonesia. (Jakarta: Graha Budaya,1998) p. 175.
} 
Chinese Ethnic was used by Demak's allies in order to control Java and the spread of Islam. This was possible because the commander of the navy who landed in Semarang, a Muslim, namely Cheng Ho. The spread of Islam on Java by the ethnic Chinese turned out to be related to the disseminating figures of Islam on Java, namely the walisongo. Four of the nine guardians of the songo are Chinese or still of Chinese descent, namely SunanAmpel, SunanBonang (son of Ampel and a Chinese woman), SunanKalijaga, and SunanGunungjati. Besides spreading Islam, this Chinese Ethnic is also authorized to run the Bandar or sea port in Semarang and Lasem. This was intended by Demak to stifle other sea ports, which were still dominated by the remains of Singasari and Majapahit such as the Tuban and Gresik sea ports. ${ }^{17}$

Some ancient relics that mention the arrival of ethnic Chinese exist both in Indonesia and in the country of China. In the inscriptions from Java the Chinese are said to be foreigners who settled alongside the names of ethnic groups from the archipelago, mainland Southeast Asia and children the Indian subcontinent. Some of the oldest records were written by clerics, such as FaHien in the 4th century and the I Ching in the 9th century. FaHien reported on a kingdom in Java ("To lo mo") and I Ching wanted to come to India to study Buddhism and stop in the archipelago to learn Sanskrit first. On Java, he studied with a person named Janabahadra. In a bronze inscription of 860 from East Java it was called a term, JuruCina, which was related to the position of caretaker of Chinese people who lived there. Some of the relief motifs in Sewu Temple are thought to also be influenced by Chinese silk cloth motifs. ${ }^{18}$

After the proclamation of Indonesian independence in 1945, when Indonesia began to deal with the legal status of Indonesian Chinese, there was difficulty in persuading the government of the People's Republic of China (PRC) to allow Indonesian Indonesians to choose their own citizenship namely RI or PRC citizenship. In 1955, it was announced that all Indonesian Chinese could choose their citizenship. And the Government of Indonesia also announced a Citizenship Act which states that all Chinese people born in the Netherlands East Indies and who have lived in Indonesia for 5 consecutive years are automatically considered Indonesian citizens.

But what happened was that the Indonesian Chinese community at that time actually held more Chinese nationality and many refused to become Indonesian nationalities. As a result, there were doubts about the loyalty of Indonesian Indonesians to the Republic of Indonesia and the Indonesian nation. Coupled with the emergence of the Sin Po group who argued that Indonesian Chinese were better oriented to the Chinese state and chose Chinese citizens. Political participation of the ethnic Chinese community has existed even from the Dutch colonial government through the Chinese organization Sun YatSen and aimed at eliminating discriminatory treatment of Chinese people in the Dutch East Indies in the fields of education, law/justice, civil status, tax burden, moving barriers and reside.

Whereas during the revolution or pre-independence period, the marginalization of Chinese citizens was seen in political news published in the mass media, as in the physical struggle, there were several fighters from the Chinese, but their names were not widely recorded and reported. One of the people identified was Tony Wen, who was involved in the

\footnotetext{
${ }^{17}$ Ibid, p. 143-144

${ }^{18}$ Kong Yuanzhi. Muslim Tionghoa Cheng Ho Misteri Perjalanan Muhibah di Nusantara. (Jakarta: Pustaka Populer Obor, 2007), p. 47-86
} 
decline of the Dutch flag at the Oranye Hotel in Surabaya. In the Old Order, there were several ministers of the Republic of Indonesia of Chinese descent such as Oei Tjoe Tat, OngEng Die, Siauw Giok Tjhan, etc. Even OeiTjoe Tat was appointed as one of the "right handers" of Ir. Soekarno during the Dwikora Cabinet.

During this time the relationship between Ir. Soekarno with several Chinese figures can be said to be very good. Although in the Old Order there were several discriminatory political policies such as Government Regulation No. 10 of 1959 which prohibited Chinese citizens from trading retail in areas outside the provincial capital and regency. This has a broad impact on the distribution of goods and ultimately becomes one of the causes of the economic downturn towards 1965 and others. In the old order era relations between Indonesia and China were very intimate, to the point that political relations between the Jakarta-Peking Axis were created.

In 1946 the Consul General of Pem. Chinese Nationalists, Chiang Chia Tung (when there was no China) with Bung Karno came to Malang and declared China as one of the big five standing behind the Republic of Indonesia. Supporting Indonesia's struggle for independence, especially in gaining international recognition for its recognition. ${ }^{19}$ The Chinese got cheers from the general public as comrades in arms. At sportsman Tony Wen's Solo stadium with his wife (Chinese film stars) called for the formation of a daring line of death (cibaku-tai, kamikaze) against the Dutch and according to the example of the 2nd generation Nisei battalion in the USA who participated in World War 2, in Malang wants to establish a Chinese battalion alongside other armed units like Laskar Rakyat, Pesindo, Kris (Menado group), Trip (students). The Chinese leadership was worried that colonial provocations could lead to armed clashes with Indigenous unity. They refused to form the battalion. Chinese people who wished to join the Dutch were encouraged to enter each of the Indigenous units according to personal suitability. However, the ethnic Chinese who were so valued in the New Order period were precisely the target of politicized mass imprisonment, because the G30S / PKI events were orchestrated by The Indonesian Communist Party, there is an assumption that communists must be Chinese, even though such an assumption is not necessarily true. The G30S / PKI incident became one of the events which greatly traumatized the ethnic Chinese in addition to the May 1998 riots. $^{20}$

The New Order government, Soeharto (1966-1998) had several explicit policies for ethnic groups through covert and indirect methods whose dissemination was supported by the media and intellectuals, so that non-ethnic Indonesian people avoided some of the ethnic groups mentioned. One ethnic minority is Chinese immigrants who have a range of around 3 (three) percent of the population.

\section{Methodology}

This research is a qualitative research with the aim of explaining the phenomenon in depth through deep data collection. ${ }^{21}$ Bogdan and Biklen ${ }^{22}$ say a qualitative approach is a research procedure that produces descriptive data in the form of written or oral words from people and observable behavior. According to Kirk and Miller as quoted by Lexy J Moleong,

\footnotetext{
${ }^{19}$ J. Babari dan Albertus Sugeng. Diskriminasi Rasial Etnis Tionghoa di Indonesia. (Jakarta: Gandi, 1999,), p. 71-72

${ }^{20}$ Ibid, p. 75

${ }^{21}$ Kriyantono,Rachmat,Teknik Praktis Riset Komunikasi, (Jakarta: Kencana Prenada Media Group,2008) P.56.

${ }^{22}$ Kholil, Syukur, Metodologi Penelitian Komunikasi, Cet 1 (Bandung: Citapustaka Media, 2006), P.121
} 
a qualitative approach is a particular tradition in social science that is fundamentally dependent on human observation in its own region or relating to people in its language and terminology. ${ }^{23}$

With this study, the data that has been collected must have been able and can explain the phenomenon under study. Therefore, a qualitative approach was carried out to obtain the depth of data from research objects, namely to explore data related to patterns of interaction between ethnic Chinese and Acehnese ethnicity, as well as ethnic Chinese communication patterns in maintaining self-existence as a minority amid the majority of Acehnese people in Lhokseumawe City. The reason the researchers used a qualitative approach in this study was as an attempt to explain the phenomenon of intercultural communication between Acehnese and ethnic Chinese in the city of Lhosekumawe in detail and depth.

To reveal the symptoms that exist in society, researchers used descriptive methods. In general, descriptive research describes an event, in another language, this study wants to understand the culture that exists in society. Descriptive method is a method in examining a group of people, an object, a set of conditions, a system of thought or a class of events in the present. The purpose of this study is to make a description, a factual and accurate systematic description of the facts of the relationship between the phenomena studied. ${ }^{24}$

\section{Discussion}

Despite having cultural differences with the Acehnese people, ethnic Chinese have been able to adapt and mingle with the Acehnese people for a long time and develop for decades. In fact, some of them already have offspring from the results of marriages with the Acehnese themselves. This proves that the Chinese ethnic community has long inhabited Aceh and mingled well and has several fantastic business entities among the people of Aceh. Likewise with ethnic Chinese in Lhokseumawe, they have various professions such as entrepreneurs, farmers, pedicab drivers, mechanics, traders, students and students and there are many other professions. The ethnic Chinese life, especially those born and living in Lhokseumawe, is certainly influenced by the environment. In the observations of the researchers, the Chinese Lhokseumawe community cannot be separated from the Acehnese in socializing because wherever there is confusion in working both garden workers, community structure structures, and in selling especially the ethnic Chinese people who have seduced Islam as if the assessment is more in the Acehnese view. For example, the process of interaction that occurs in the business environment or traders in Lhokseumawe.Lhokseumawe traders are very influential with the existence of ethnic Chinese because the process of economic growth is largely determined by ethnic Chinese who dominate the area, researchers observed JalanPasarLhokseumawe, the atmosphere of Chinese ethnic transactions dominates the market if we look at sustainable stores to pharmacy stores central. Chinese ethnic principles in transacting in the market in the form of wholesale up to Rp. 2 (two) Million Rupiah in one family for kitchen needs in one purchase even in some supermarkets or minimarkets, they can spend almost Rp. 2 (two) million rupiah to buy family daily necessities.

Abdul Razak was one of the traders who the researcher had met explaining that, ethnic Chinese he strongly believed in ethnic Chinese in debt to him, because in general

\footnotetext{
${ }^{23}$ Lexy J. Moleong,Metodelogi penelitian Kualitatif, (Bandung: Remaja Rosda karya 1995), P.3

${ }^{24}$ Nazir, Moh, Metode Penelitian, Cet.4 (Jakarta: Ghalia Indonesia,1999) p.63
} 
ethnic Chinese very rarely cheat with sellers here. Even though we were very close to them for decades they had known us and even according to Razak ethnic Chinese in Lhokseumawe had become our adopted brothers. In Lhokseumawe there are rarely propaganda words for ethnic groups even when the Ahok case in Jakarta even though the Lhokseumawe people still harmonize with Chinese ethics especially during Lhokseumawe during the turmoil of the Free Aceh Movement before ethnic Chinese people were harmed, because here very blend between other ethnic groups, let alone hostile and drive him away, for him is very unlikely to occur and for him will feel lost both in the form of business and family. ${ }^{25}$

\section{Conclusion}

The pattern of ethnic Chinese communication in Lhokseumawe within the indigenous community in Lhokseumawe City was carried out with cultural adaptation. Chinese ethnic communities try to find sympathy for indigenous people by prioritizing symbolic interaction and identity manipulation, can be felt by this pattern, the Lhokseumawe indigenous people have never dispute with Chinese ethnic communities, so it feels harmony that occurs in all aspects, both in social, cultural and trade.

\section{References}

Amin, Samsul Munir, Ilmu Dakwah, Jakarta: Amzah, 2009

Arasaratnam, A. Lily, Perception and Communication in Intercultural Spaces, United Kingdom: University Press of America, 2001

Arasaratnam, Lily A, Perception And Communication In Intercultural Spaces, United Kingdom: University Press, 2001

Craib, IAI, Teori-Teori Sosial Modern, Jakarta : Raja GrafindoPersada,1994

Deddy Mulyana, Metodelogi Penelitian Kualitatif, Paradigma Baru Ilmu Komunikasi dan Sosial Lainnya Bandung: Remaja Rosdakarya, 2001

Lestari Pambayun, Ellys, Communication Quotient, Bandung: Remaja Rosdakarya, 2012

Garna K Judistira, Metode Penelitian Pendekatan Kualitatif, Bandung: Primaco Akademika 1999 Gudykunst, Kim, Communicating With Strangers, An Approach To Interculture Communication, USA: Mc Graw Hill.Inc, 1992

Gudykunst, William B. Bridiging Differences-Effective Intergroup Communication, London: Sage Publication, 1991

Kholil, Syukur, Metodologi Penelitian Komunikasi, Cet 1 Bandung: Citapustaka Media, 2006

Lexy J. Moleong, Metodelogi Penelitian Kualitatif, Bandung: Remaja Rosda karya 1995

Liem, Yusiu, Prasangka Terhadap Etnis Cina, Jakarta: Djambatan, 2000

Liliweri, Alo, Dasar-Dasar Komunikasi Antar Budaya, Cet. 3, Yogyakarta: Pustaka Pelajar,2007

Morissan, Teori Komunikasi Individu Hingga Massa, Jakarta: Kencana, 2014

Muis, A., Komunikasi Islami, Bandung: Remaja Rosdakarya, 2001

Mulyana, Deddy, Komunikasi Efektif, Cet-3, Bandung: Rosdakarya, 2008 , Metode Penelitian Komunikasi Kualitatif, Bandung: Remaja RosdaKarya,2010

Munawir, A.W., Kamus Al-MunawwirArab-Indonesia Terlengkap, Surabaya: Pustaka Progressif, 1997

Mustafa Al Maraghi, Ahmad, Tafsir Al Maraghi, Cet. III, Jilid. V,Juz. 15, Beirut: Dar Al Fikr, 1974

${ }^{25}$ Abdul Razak, Masyarakat Etnik Aceh, RazaqnaMinimarket Owner, 12 Maret 2017 di Lhokseumawe 